\title{
Utilization of Filamentous Phage $\phi R S M 3$ to Control Bacterial Wilt Caused by Ralstonia solanacearum
}

Hardian S. Addy, Ahmed Askora, Takeru Kawasaki, Makoto Fujie, and Takashi Yamada, Department of Molecular Biotechnology, Graduate School of Advanced Sciences of Matter, Hiroshima University, Higashi-Hiroshima 739-8530, Japan

\begin{abstract}
Addy, H. S., Askora, A., Kawasaki, T., Fujie, M., and Yamada, T. 2012. Utilization of filamentous phage $\phi$ RSM3 to control bacterial wilt caused by Ralstonia solanacearum. Plant Dis. 96:1204-1209.

The wide host range of Ralstonia solanacearum, causal agent of bacterial wilt, and its ability to survive for long periods in the environment restrict the effectiveness of cultural and chemical control measures. The use of phages for disease control is a fast-expanding trend of plant protection with great potential to replace chemical measures. The filamentous phage $\phi R S M 3$ that infects $R$. solanacearum strains and inactivates virulence on plants is a potential agent for controlling bacterial wilt in tomato. We demonstrated that inoculation of $\phi R S M 3$-infected cells into tomato plants did not cause bacterial wilt. Instead, $\phi R S M 3-$

infected cells enhanced the expression of pathogenesis-related $(P R)$ genes, including $P R-1 a, P R-2 b$, and $P R 7$, in tomato plants. Moreover, pretreatment with $\phi R S M$-infected cells protect tomato plants from infection by virulent $R$. solanacearum strains. The effective dose of $\phi R S M 3$-infected cells for disease prevention was determined to be approximately $10^{5} \mathrm{CFU} / \mathrm{ml}$. Because the $\phi R S M 3$-infected cells can grow and continue to produce infectious phage particles under appropriate conditions, $\phi \mathrm{RSM}$ phages may serve as an efficient tool to control bacterial wilt in crops.
\end{abstract}

Bacterial wilt, caused by Ralstonia solanacearum, is an important plant disease of many crops, damaging more than 200 species in 50 botanical families, occurring widely in the world, and persisting in the environment (24). Some management strategies are currently employed to control this disease such as chemical control, soil treatment, crop rotation, and resistant plants (14). Although soil treatments such as modification of soil $\mathrm{pH}$ or heat have occasionally been effective in suppressing the pathogen, they are limited to small-scale agriculture and are unfriendly to the environment (8). Crop rotation has not been effective, because $R$. solanacearum has a wide host range and survives for long periods in the soil (2). Although the use of resistant plant cultivars has been reported to be the most reliable method to control bacterial wilt, it is not completely effective because cultivars exhibit reduction in yield and plant quality, often lacking in stability or durability $(7,24)$. Thus, alternative control methods for bacterial wilt, which are more effective, safer to applicators, and have lower environmental impact, are still needed.

Various studies have indicated that biological control of bacterial wilt could be achieved using antagonistic bacteria $(10,27)$. Rhizobacteria like Bacillus spp. (31), Pseudomonas spp. (23), and Streptomyces spp. (17) are examples of bacteria with efficacy. Another potential biological agent to control bacterial wilt caused by $R$. solanacearum is avirulent mutants of $R$. solanacearum (15) through spontaneous or genetic mutation. Recently, we reported that filamentous $\phi R S M$-type phages ( $\phi R S M 3$ is a typical phage of this group) changed host bacterial cells to be avirulent after infection (5). Numerous studies reported that the use of avirulent strains could reduce disease severity. Avirulent strains of Erwinia amylovora and $E$. chrysanthemi reduced fire blight disease on apple (34) and soft rot disease on saintpaulia plants (Saintpaulia ionantha)

Corresponding author: T. Yamada, E-mail: tayamad@hiroshima-u.ac.jp

* The $e$-Xtra logo stands for "electronic extra" and indicates that Figures 1, 2 , and 4 appear in color online.

Accepted for publication 13 March 2012.

http://dx.doi.org/10.1094/PDIS-12-11-1023-RE

(c) 2012 The American Phytopathological Society
(30), respectively. Ciardi et al. (11) reported that an avirulent strain of Xanthomonas campestris pv. vesicatoria increased the tolerance of tomato plants against bacterial spot disease. Similar effects were also demonstrated by avirulent strains of $R$. solanacearum against bacterial wilt in some plants $(32,35)$.

Mechanisms underlying the control of bacterial diseases by avirulent strains are thought to involve production of bacteriocins and induction of plant resistance $(4,9)$. Stem inoculation in tomato by an avirulent strain of the bacteria Clavibacter michiganensis subsp. michiganensis induced long-lasting, high-level-protection against the virulent bacterial strain (22). An avirulent strain of Pseudomonas syringae pv. pisi was shown to induce systemic acquired resistant (SAR) in pea (13). Moreover, Edreva (16) described a detailed mechanism by which an avirulent strain induces plant resistance via SAR through a salicylate acid signaling pathway.

The aim of this research was to demonstrate the application of filamentous phage $\phi \mathrm{RSM}$ to control bacterial wilt in tomato caused by $R$. solanacearum.

\section{Materials and Methods}

Bacterial strains and bacteriophage. $R$. solanacearum strain MAFF (The Ministry of Agriculture, Forestry, and Fisheries of Japan) 106603 (race 1, biovar 3, and phylotype I) was from the National Institute of Agrobiological Sciences (Japan). Avirulent strain M4S (race 1, biovar 3, and phylotype 1) was from the Leaf Tobacco Research Center, Japan Tobacco Inc. (33). The bacterial cells were cultured in CPG medium containing $0.1 \%$ casamino acids, $1 \%$ peptone, and $0.5 \%$ glucose at $28^{\circ} \mathrm{C}$ with shaking at 200 to $300 \mathrm{rpm}$ (25). Strain MAFF 106603 carrying a green fluorescent protein (GFP)-expressing plasmid pRSS12 was described previously (26) and was cultivated in CPG containing kanamycin (50 $\mu \mathrm{g} / \mathrm{ml})$. In some cases, bacterial cells were cultivated in minimal medium (MM) containing $1.75 \mathrm{~g}$ of $\mathrm{K}_{2} \mathrm{HPO}_{4}, 0.75 \mathrm{~g}$ of $\mathrm{KH}_{2} \mathrm{PO}_{4}$, $0.15 \mathrm{~g}$ of Na-citrate, $0.25 \mathrm{~g}$ of $\mathrm{MgSO}_{4}$, and $1.25 \mathrm{~g}$ of $\left(\mathrm{NH}_{4}\right)_{2} \mathrm{SO}_{4}$ per liter (6). Bacteriophage $\phi R S M 3$ (a member of filamentous $\phi R S M-t y p e$ phages belonging to the family Inoviridae) was described previously by Askora et al. (5). $\phi$ RSM3 was routinely propagated using strain MAFF 106603 as the host. To collect sufficient phage particles, a total of 2 liters of bacterial culture was grown. When the cultures reached 0.1 unit at an optical density at $600 \mathrm{~nm}\left(\mathrm{OD}_{600}\right)$, the phage was added at a dose of 0.01 to 0.05 
PFU/host cell. After further growth for 16 to $18 \mathrm{~h}$, cells were removed by centrifugation in an R12A2 rotor in a Hitachi Himac CR21E centrifuge (Hitachi Koki Co. Ltd.), at 8,000 $\times g$ for $15 \mathrm{~min}$ at $4^{\circ} \mathrm{C}$. The supernatant was passed through a $0.2-\mu \mathrm{m}$ membrane filter and then phage particles were precipitated in the presence of $0.5 \mathrm{M} \mathrm{NaCl}$ and $5 \%$ polyethylene glycol 6000 . Phage preparations were stored at $4{ }^{\circ} \mathrm{C}$ until use. To isolate single colonies of MAFF 106603 infected with $\phi$ RSM3, single $\phi$ RSM3 plaques picked from assay plates covered with a MAFF 106603 lawn were streaked onto CPG plates. Single colonies were purified by repeated picking and streaking on CPG plates. The phage genomic DNA was isolated from cells in its replicative form and confirmed by restriction enzyme digestion.

In planta monitoring movement of bacterial cells. For realtime monitoring of $R$. solanacearum cells in planta, tomato seedlings were grown on agar medium and bacterial suspension was applied to the root apex as previously described $(19,20)$. Briefly, seed of tomato (Solanum lycopersicum L) 'Oogata-fukuju' was obtained from Takii Co., Ltd.. For aseptic cultures, seed were surface sterilized with sodium hypochlorite containing 1 drop of Tween 20 and cultured in a square dish (sterile square Schale Number 2; Eiken Chemical Co., Ltd.) containing solid medium $(0.15 \%$ Hyponex powder [Hyponex Japan Corp., Ltd.], 0.5\% sucrose, and $1.5 \%$ agar, adjusted to $\mathrm{pH} 5.8$ ) as described before (20). Plants were grown in a growth chamber (Sanyo Growth Cabinet) at $28^{\circ} \mathrm{C}$ under a photoperiod of $16 \mathrm{~h}$ of light and $8 \mathrm{~h}$ of darkness. During the culture period, the dishes in the chamber were tilted to a $45^{\circ}$ angle to encourage roots to grow the surface of the medium. To inoculate into plants, bacterial cells of a GFP-expressing strain ( $\phi$ RSM3-infected or uninfected MAFF 106603 harboring pRSS12)
$(19,26)$ were cultured in CPG medium, and suspended in sterile distilled water at a density of $1 \times 10^{8}$ cells $/ \mathrm{ml}$. Tomato seedlings grown in culture dishes ( 9 days old) were cut at the tip of the taproot, $10 \mathrm{~mm}$ from the apex, with a razor blade; then, $1 \mu \mathrm{l}$ of bacterial suspension was applied to the cut. After inoculation, the plants in the dishes were cultured in the growth chamber until observation. In each experiment, five seedlings were treated with $\phi$ RSM3infected cells and five with wild-type cells for control. Experiments were repeated three times. Bacterial cells in the plants were observed using an MZ16F fluorescence stereomicroscope (Leica Microsystem) equipped with GFP2 and GFP3 filters or an Olympus $\mathrm{BH} 2$ fluorescence microscope (Olympus). Microscopic images were recorded with a CCD camera (Keyence VB-6010).

Virulence assays. Cells of $R$. solanacearum were grown in CPG medium for 1 to 2 days at $28^{\circ} \mathrm{C}$. After centrifugation, cells were resuspended in double-distilled $(\mathrm{dd}) \mathrm{H}_{2} \mathrm{O}$ at a density of $10^{8}$ cells $/ \mathrm{ml}\left(\mathrm{OD}_{600}=0.3\right)$. For the virulence assay, the bacterial cell suspension $(1 \mu \mathrm{l})$ was injected with a needle into the major stem of tomato plants ( 4 to 6 weeks old with four leaves) at a site between the cotyledon and the first leaf. As a control, $\mathrm{ddH}_{2} \mathrm{O}$ at the same density was injected in the same manner. Each bacterial strain was injected into five plants. Plants were cultivated in a Sanyo Growth Cabinet at $28^{\circ} \mathrm{C}$ ( $16 \mathrm{~h}$ of light and $8 \mathrm{~h}$ of darkness) for up to 1 week before evaluation of disease symptoms. The wilting symptoms were graded from 0 to 4 as described by Winstead and Kelman (37) and modified by Poueymiro et al. (29). To test the ability of $\phi R S M 3$-infected cells to protect plants against subsequent infection by virulent cells, tomato seedlings were first injected with $\phi$ RSM3-infected, MAFF 106603 cells, or the control as described above. The tomato plants were then injected with virulent cells

Table 1. List of primers used in quantitative reverse-transcriptase polymerase chain reaction

\begin{tabular}{llcc}
\hline Primer name & \multicolumn{1}{c}{ Oligo sequences $\left(\mathbf{5}^{\prime} \rightarrow \mathbf{3}^{\prime}\right)$} & Target gene & Product (bp) \\
\hline ACT-F & GTTGGACTCTGGTGATGGTGTTAG & $\beta$-actin & 231 \\
ACT-R & GTTTCAAGTTCCTGCTCGTAGTCA & PR1a & 165 \\
PR1a-F & TCCGAGAGGCCAAGCTATAACTAC & & 336 \\
PR1a-R & GCCTACAGGATCATAGTTGCAAGA & $P R 2 b$ & 389 \\
PR2b-F & CAGGACAGATTTCACTTCCGTATG & & \\
PR2b-R & AATGCTTCTCAAGCTCTGGATTCT & $P R 7$ & \\
PR69-F & CGAATTTGAAACACCTTATTGCAG & & \\
PR69-R & CGATTATGTCAGGTTTCAAGATGC & & \\
\hline
\end{tabular}

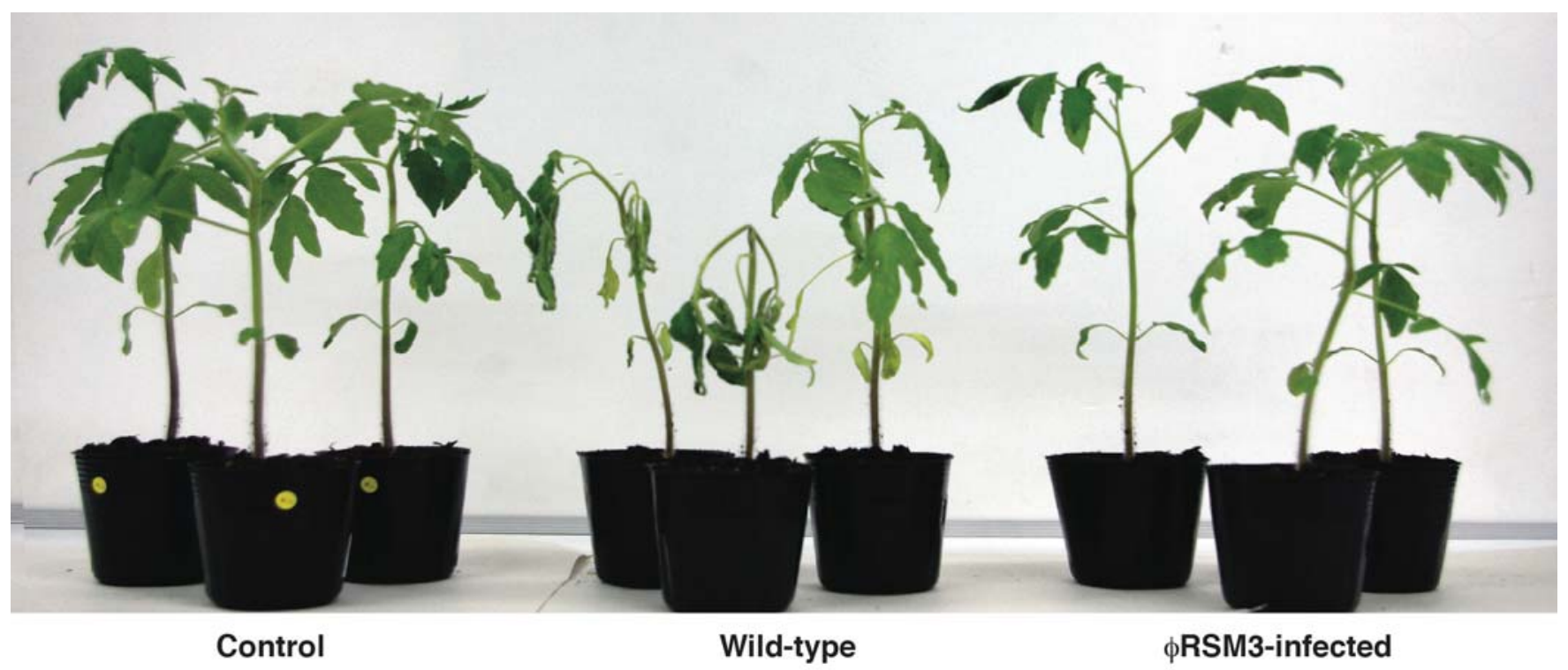

Fig. 1. Effects of $\phi R S M 3$ infection on Ralstonia solanacearum virulence. Tomato plants (4 weeks old) were injected with cells of MAFF 106603 uninfected or infected by $\phi R S M 3$. As a control, plants were injected with double-distilled $\mathrm{H}_{2} \mathrm{O}$. Each bacterial strain was injected into 20 plants (3 displayed as examples). All plants injected with $\phi R S M 3-$ uninfected $R$. solanacearum cells showed wilting symptoms 1 week after injection. All plants injected with $\phi R S M 3$-infected cells or control showed no wilting symptoms. 
(MAFF 106603) at approximately 10 to $20 \mathrm{~mm}$ above the first injection point after various intervals ( 1 or 4 days, 1 or 2 weeks, or 1 or 2 months after the first injection). Wilting symptoms were evaluated as described above. Each bacterial strain was injected into 20 plants. The experiment was repeated three times.

Real-time quantitative reverse-transcription polymerase chain reaction. Real-time quantitative reverse-transcription polymerase chain reaction (qRT-PCR) was performed as described previously (3). First-strand cDNAs were synthesized from $1 \mu \mathrm{g}$ of total RNA with a ReverTraAce reverse-transcriptase kit (Toyobo) and oligo dT primers according to the manufacturer's instructions.
Specific gene primers were designed using Primer 3 (v. 0.4.0) software for real-time PCR. The negative control (to eliminate the possibility of residual DNA amplification) consisted of the same reaction except that the reverse transcriptase was omitted from the reaction mixture. Real-time qRT-PCR was performed with a SYBR premix Ex Taq kit (TakaraBio) using a LineGene fluorescence quantitative detection system (BioFlux). The $10 \mu \mathrm{l}$ of reaction mixture contained $5 \mu \mathrm{l}$ of SYBR premix Ex Taq, $1 \mu \mathrm{l}$ of diluted cDNA, and $0.5 \mu \mathrm{M}$ each gene primer (Table 1 ). PCR was performed under the following conditions: initial heating for $3 \mathrm{~min}$ at $95^{\circ} \mathrm{C}$ and 45 cycles of $95^{\circ} \mathrm{C}$ for $10 \mathrm{~s}, 62^{\circ} \mathrm{C}$ for $10 \mathrm{~s}$, and $72^{\circ} \mathrm{C}$ for $15 \mathrm{~s}$. At the

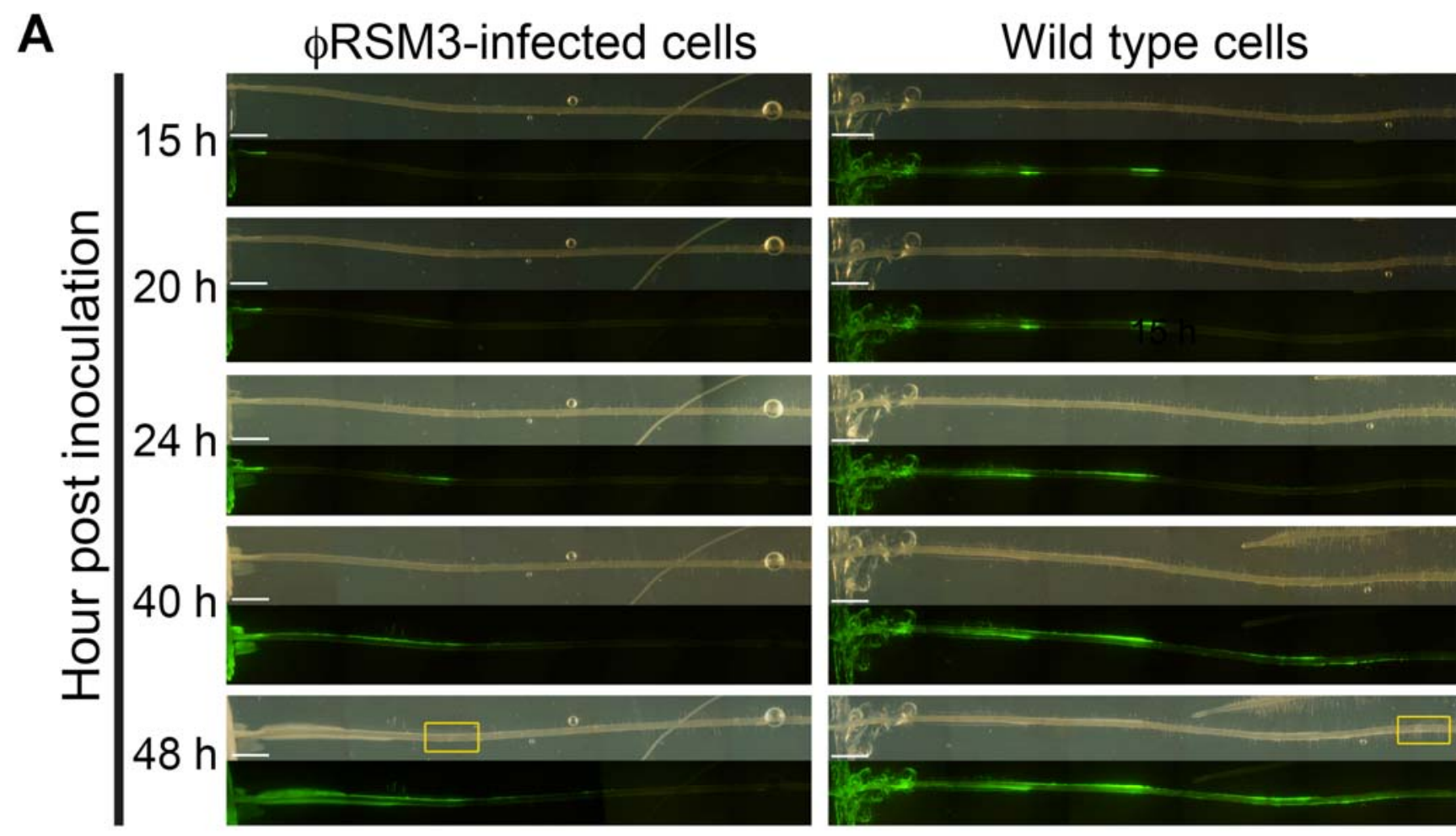

B

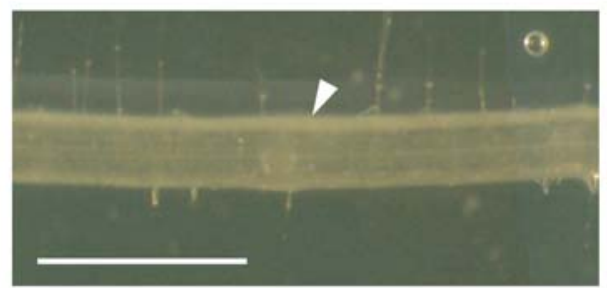

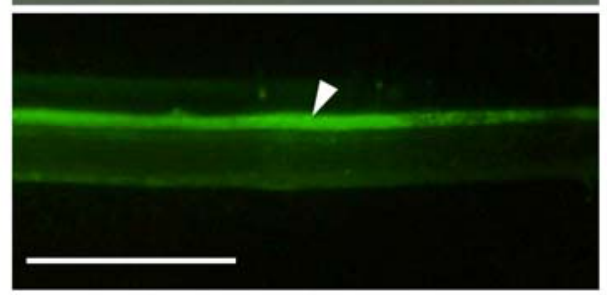

$\phi R S M 3-i n f e c t e d$ cells
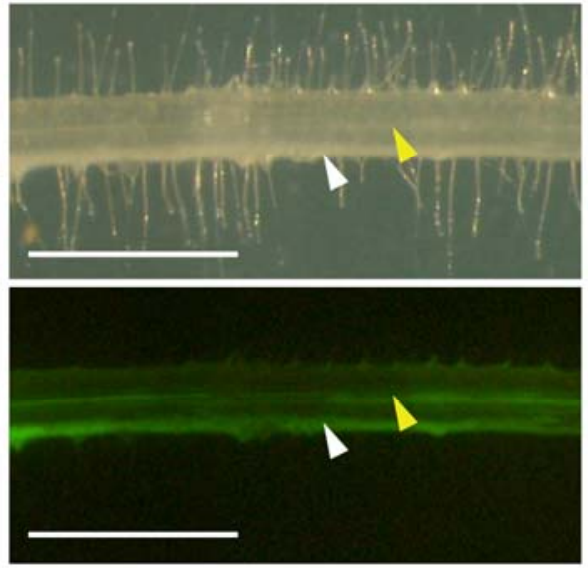

Wild type cells

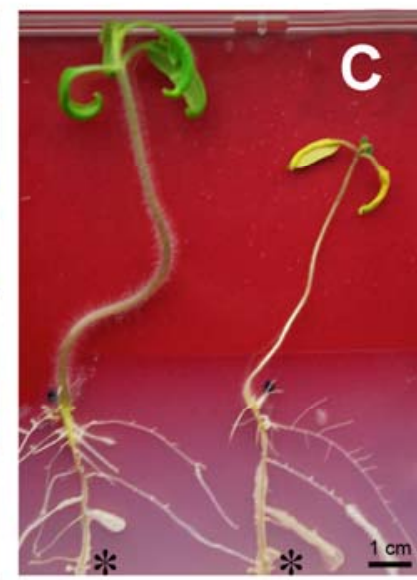

$\phi R S M 3$-infected

cells

Fig. 2. In planta inhibition of Ralstonia solanacearum movement caused by $\phi R S M 3$ infection. Tomato seedlings inoculated with $\mathbf{A}$, noninfected bacterial cells (right) and фRSM3-infected cells (left) are compared. Green fluorescent protein (GFP) fluorescence from bacterial cells was observed at various times post inoculation (upper panel, bright-field image; lower panel, dark-field image). Bacterial penetration into the taproot, successive upward movement, and growth in the tissue was vigorous in the control seedling (inoculated with noninfected bacteria). Colonization of bacterial cells in the taproot was observed (yellow arrowhead). B, Comparison of the moving front of bacterial cells (local area boxed in A) at a higher magnification (upper panel, bright-field image; lower panel, dark-field image). Bacterial cells were observed to emerge from plant tissues of the seedling inoculated with uninfected cells. Bacterial growth and upward movement in the taproot were limited in seedling inoculated with $\phi R S M 3$-infected cells and main GFP signal was due to the cells colonized the taproot surface (white arrowhead). C, Wilting symptom of tomato seedlings (10 days post inoculation). The control seedling inoculated with noninfected cells completely died, whereas the seedling with $\phi R S M 3$-infected cells remained healthy without any wilting symptoms. White bars indicate $3 \mathrm{~mm}$. Asterisk ${ }^{*}$ ) refers to site of inoculation. 
end of the program, the specificity of the primer set was confirmed by melting curve analysis $\left(65\right.$ to $95^{\circ} \mathrm{C}$ with a heating rate of $0.5^{\circ} \mathrm{C} / \mathrm{min}$ ). Relative expression levels were calculated as the ratio of expression of each gene against the $\beta$-actin gene in tomato. Each experiment was repeated three times.

\section{Results}

Loss of virulence in $\phi R S M 3$-infected $R$. solanacearum. In our previous work, Askora et al. (5) observed that $\phi$ RSM-infected cells of $R$. solanacearum showed avirulent phenotypes. We confirmed this with cells at various densities. When a $1-\mu l$ cell suspension containing $10^{5}$ (CFU) cells of MAFF 106603 was injected into the major stem of tomato plants (4 to 6 weeks old with four leaves), all
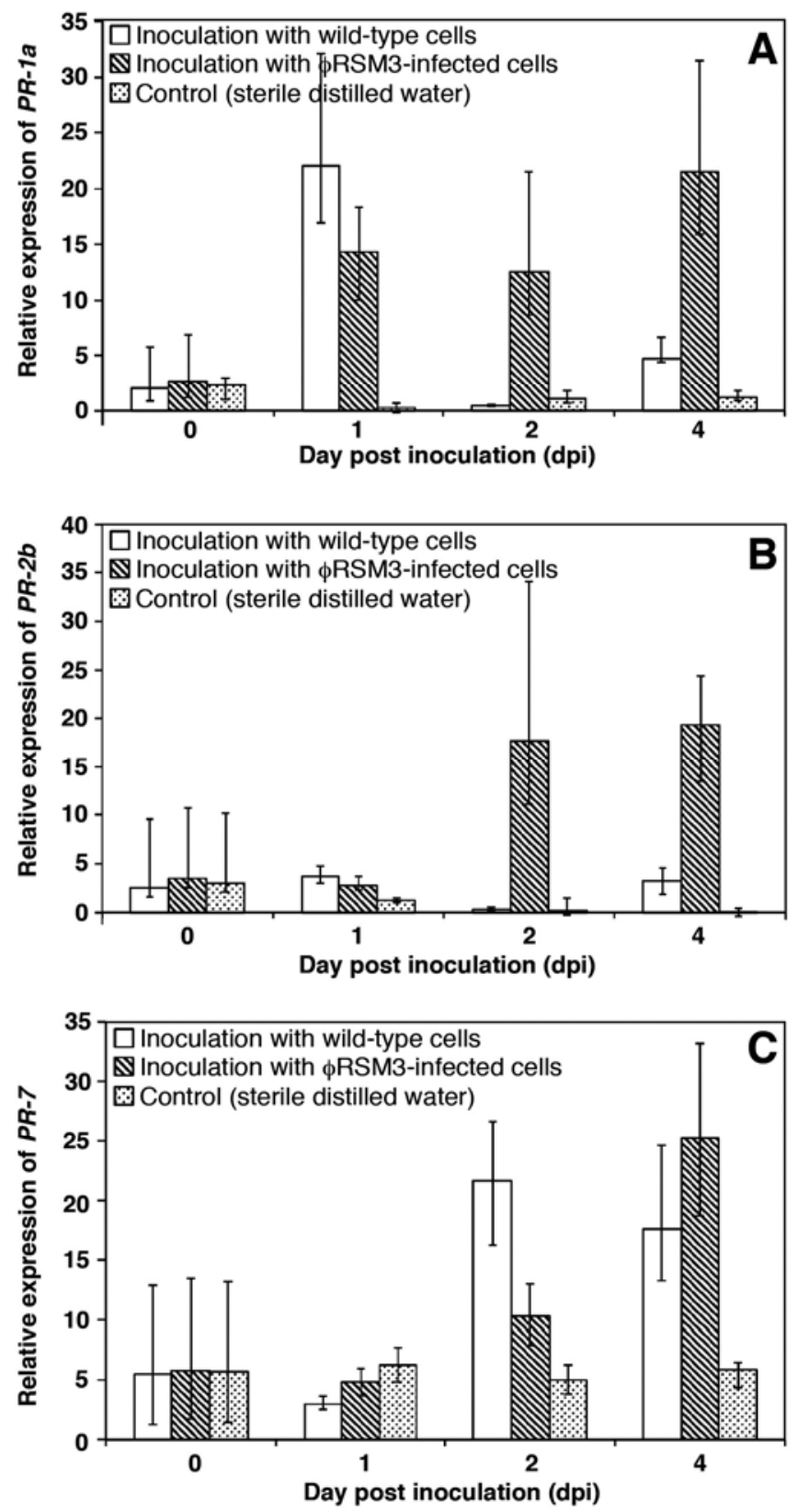

Fig. 3. Expression analysis of tomato genes involved in defense responses: pathogenesis-related $(P R)$ genes A, PR-1a; B, PR-2b; and C, PR-7. Transcript levels of each gene were determined by quantitative reverse-transcription polymerase chain reaction from cDNAs isolated from leaves of tomato plants injected with $\phi R S M 3$-infected bacterial cells ( $\phi R S M 3$ plant), with uninfected cells (no-phage plant), or with double-distilled $\mathrm{H}_{2} \mathrm{O}$ (control). Expression value of each gene was normalized to that of the $\beta$-actin gene as an internal standard, and is shown as a relative values. Mean expression and standard deviation values were calculated from the results of three independent experiments. plants showed wilting symptoms as early as 3 days post inoculation (dpi) and died 5 to 7 dpi (Fig. 1). In contrast, all 20 plants injected with $\phi R S M 3$-infected MAFF 106603 cells showed no wilting symptoms until 4 weeks post inoculation. This was also the case with other host strains such as MAFF 106611; $\phi$ RSM3infected MAFF 106611 completely lost its virulence against tomato plants (data not shown). Bacterial growth and movements were monitored in real time under a fluorescent microscope. As indicated by GFP fluorescence, the bacterial cells accumulated in the xylem vessels and rapidly moved upward in tomato seedlings inoculated with noninfected bacteria (Fig. 2A). After inoculation, fluorescence intensity increased with time, indicating vigorous growth of bacterial cells. Meanwhile, most of the $\phi R S M 3$-infected bacterial cells remained around the injection point (within $3 \mathrm{~mm}$ from the injection point), and their movement and growth were severely limited (Fig. 2A). Local taproot areas at the frontier of bacterial movement (Fig. 2A, box) were compared at a higher magnification in Figure 2B. In the seedling with $\phi$ RSM3-infected bacterial cells, bacterial cells were limited around the inoculation point and the observed GFP signal was due to cells colonized outside the taproot, whereas bacterial cells multiplying and moving upward were eventually emerging from the xylem tissues and even covered the root surface. Seedlings inoculated with uninfected bacterial cells showed wilting symptoms 4 to 5 dpi and completely died $10 \mathrm{dpi}$, whereas seedlings with $\phi$ RSM3-infected cells showed no wilting symptoms and remained healthy (Fig. 2C). Three repeated experiments showed statistically equivalent results.

Induction of pathogenesis-related genes in tomato by $\phi R S M 3-i n f e c t e d$ bacterial cells. The observation that $\phi$ RSM3infected bacterial cells were inhibited to grow and move in the inoculated tomato seedlings led us to examine the expression levels of some defense-related genes in the treated plants. After injection of bacterial cells (strain MAFF 106603), the tomato leaf just above the injection site was picked from each plant and subjected to the processes of RNA extraction and qRT-PCR. The expression of three pathogenesis-related $(P R)$ genes, including those for $P R-1 a$ (an acidic $P R$ gene), $P R-2 b$ (a basic $P R$ gene), and $P R-7$ (tomato P69) (36) was compared among plants with $\phi R S M 3$-infected cells ( $\phi$ RSM3 plants), plants with uninfected cells (no-phage plants), and $\mathrm{ddH}_{2} \mathrm{O}$-injected plants (control). Data shown in Figure 3 indicated that the $P R-1 a$ gene was highly expressed in both no-phage plants and $\phi R S M 3$ plants $1 \mathrm{dpi}$, and the expression level sharply decreased 2 dpi in no-phage plants. Meanwhile, the high expression levels continued until 4 dpi in $\phi R S M 3$ plants (Fig. 3A). In the case of $P R-2 b$, its expression was very low in no-phage plants until 4 dpi whereas significant levels of expression were detected after 2 dpi in $\phi R S M 3$ plants (Fig. 3B). The expression of the gene for $P R$ 7 was induced 2 dpi and continued until 4 dpi in both $\phi R S M 3$ plants and no-phage plants. However, $P R-7$ expression started more slowly in response to phage-infected cells but its levels were higher in $\phi$ RSM3 plants than in no-phage plants (Fig. 3C). In control plants, the expression of these three genes was consistently low. In $\phi R S M 3$ plants, the expression of the defense genes was stably activated and maintained at high levels, likely due to reduced activity of virulence genes, including $h r p B$, responsible for type III effector secretion in $\phi$ RSM3-infected bacterial cells. In all three repeated experiments, similar results were observed.

Pretreatment of tomato seedlings with $\phi$ RSM3-infected $R$. solanacearum cells protected plants from subsequent infection by virulent cells. In addition to their loss of virulence, $\phi$ RSM 3 infected cells protected tomato plants against subsequent challenge with virulent $R$. solanacearum cells. Tomato plants were inoculated with $\phi R S M 3$-infected MAFF 106603 cells as described above. Then, 1 day later, plants were injected with noninfected virulent bacteria at approximately 10 to $20 \mathrm{~mm}$ above the first injection point. No wilting symptoms were observed in $\phi R S M 3-$ treated plants for at least 4 weeks after inoculation (Fig. 4), whereas control plants without $\phi$ RSM3-infected cells or those that had been pretreated with Escherichia coli cells all died within 1 week. Under standard virulence assay conditions (see Materials 

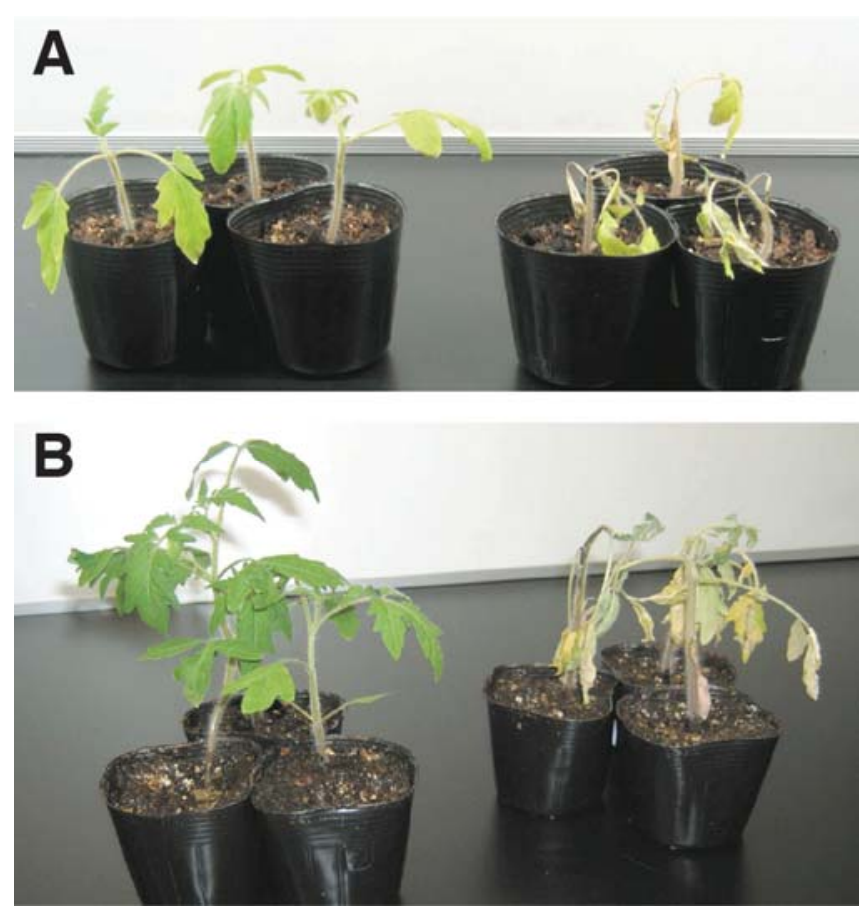

Fig. 4. Enhanced resistance against subsequent infection by virulent cells in tomato seedlings pretreated with $\phi R S M 3$-infected cells. Tomato seedlings (10 days old) were first injected with $\phi R S M 3$-infected cells (left) or Escherichia coli JM109 (right). Tomato plants were then injected with virulent cells (MAFF 106603) after various intervals (A, 1 day or B, 2 weeks). All plants pretreated with $\phi R S M 3$-infected cells grew normally and showed no wilting symptoms. All control plants showed wilting symptoms and died within 1 week after the second injection.

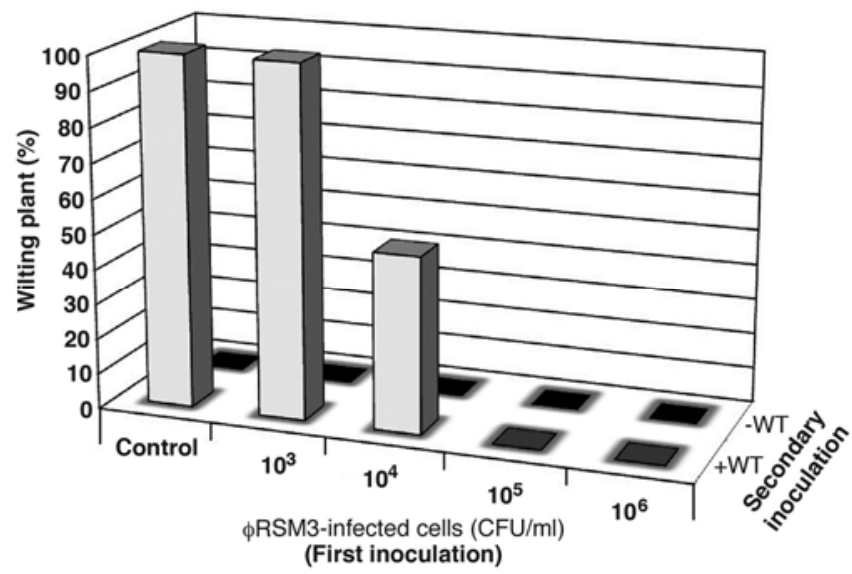

Fig. 5. Dose effects of $\phi R S M 3$-infected cells for protecting plants against second inoculation of virulent cells. One week after the first injection with $\phi R S M 3$-infected cells at different doses, the tomato plants were inoculated with virulent bacterial cells. Wilting symptoms were evaluated as described above. Twenty plants were subjected to each assay. and Methods), effective doses of $\phi R S M 3$-infected cells were determined. $\phi$ RSM3-infected cells at a density lower than $10^{3} \mathrm{CFU} / \mathrm{ml}$ showed no prevention effects, $50 \%$ protection was observed at $10^{4}$ $\mathrm{CFU} / \mathrm{ml}$, and all plants survived with cell density greater than $10^{5}$ CFU/ml (Fig. 5). This wilt-prevention effect was observed in plants as young as 1 week old (data not shown). Two months after the treatment with $\phi R S M 3$-infected cells, inoculation with virulent cells could not cause wilting symptoms (Table 2). Therefore, once plants were treated with $\phi$ RSM3-infected cells, the prevention effect lasted for up to 2 months (Table 2). Similar protective effects against infection by MAFF 106603 were also achieved by treating tomato plants with $\phi$ RSM3-infected MAFF 106611 or M4S (a spontaneously occurring avirulent strain) (28) as well as MAFF 211271 (race 3) and MAFF 211272 (race 4) (data not shown).

\section{Discussion}

Like other filamentous Ff-type phages (Inoviridae), infection with $\phi$ RSM3 does not cause host bacterial cell lysis. Instead, it establishes a persistent association between the host bacteria and phage, releasing phage particles from the growing host bacterial cells. Therefore, infection by phage can mediate conversion of the host bacterial phenotype. Upon infection by $\phi R S M 3$, host cells demonstrate complete loss of virulence. The loss of virulence in host bacterial cells is caused by repression of some host genes, including $p h c A$ and $h r p B$, by phage-encoded open reading frame 15 (1). Furthermore, once inoculated with $\phi$ RSM3-infected $R$. solanacearum cells, plants showed stable resistance upon inoculation with virulent bacteria. This resistance was induced as early as $1 \mathrm{dpi}$ and lasted for up to 2 months. After inoculation of bacterial cells into tomato plants, $P R$ genes $(P R-1 a, P R-2 b$, and $P R-7)$ were highly expressed in $\phi R S M 3$ plants, especially at 4 dpi. In the case of $P R-1 a$, the expression level was high in both no-phage plants and $\phi$ RSM 3 plants as early as $1 \mathrm{dpi}$ but it sharply decreased $2 \mathrm{dpi}$ in no-phage plants. This blockage of host response by wild-type (no-phage) bacterial cells may be caused through the type III secretion system (T3SS) that allows the translocation of effector proteins into plant cells (21). Contrasting to this, the high expression levels of $P R-1 a$ continued until 4 dpi in $\phi R S M 3$ plants, suggesting reduced activity of T3SS in $\phi R S M 3$-infected bacterial cells. Actually, the expression of $h r p B$, the regulator gene of T3SS-encoding and effector genes (12), was reduced in $\phi R S M 3$-infected bacterial cells (1). The expression of $P R-7$ started more slowly in response to phage-infected cells but its levels became much higher in $\phi$ RSM3 plants than in no-phage plants at $4 \mathrm{dpi}$. This looks like a general resistance response (36) overlaid with a specific response to the $\phi R S M 3$-infected $R$. solanacearum. This specific response was also seen in the expression of $P R-2 b$, which was very low in non-phage plants until 4 dpi.

Because the $\phi$ RSM-infected cells can grow and continue to produce infectious phage particles under appropriate conditions, $\phi R S M$ phages may serve as an efficient tool to control bacterial wilt in crops by decreasing the virulence of the pathogen. The use of avirulent mutants of $R$. solanacearum for bacterial wilt biocontrol has already been reported $(32,35)$, and the protective nature of such pre-interactions on tomato plants is established. Compared with avirulent mutants, advantages of the $\phi R S M 3$-infected cells can be explained as follows. $\phi$ RSM phages with compensating host ranges infect a wide range of strains of different races. Askora et

Table 2. Prevention of the second infection through $\phi R S M 3$-pretreatment in tomato

\begin{tabular}{|c|c|c|c|c|c|c|}
\hline \multirow[b]{2}{*}{ Strains } & \multicolumn{6}{|c|}{ Interval between the first and second injections ${ }^{a}$} \\
\hline & 1 day & 4 days & 1 week & 2weeks & 1 month & 2 months \\
\hline MAFF 106603 ( $\phi$ RSM3) & - & - & - & - & - & - \\
\hline MAFF 106611 ( $\phi$ RSM3) & - & - & - & - & - & - \\
\hline M4S & - & - & - & - & - & - \\
\hline Escherichia coli JM109 & + & + & + & + & + & + \\
\hline
\end{tabular}

a Symbols: $+=$ wilting 1 week after injection with the second virulent cells (MAFF 106603) and $-=$ no wilting 1 week after injection with the second virulent cells (MAFF 106603). 


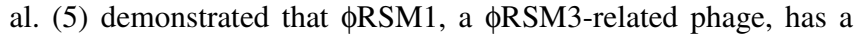
host range different from that of $\phi \mathrm{RSM} 3$. All tested strains of $R$. solanacearum of different races or biovars were susceptible to one of the two phages (5). It is likely that a mixture of $\phi R S M 1$ and $\phi R S M 3$ would be particularly effective against field-isolated, uncharacterized $R$. solanacearum strains. Moreover, infection with $\phi \mathrm{RSM}$ phage is very easy and reliable. There is no need of mutagen treatment or transposon introduction and following selection and characterization before use. After inoculation into plants, $\phi$ RSM phage released from infected cells can infect new susceptible cells, so that the protection effects can be long lasting. This contrasts with the case of biocontrol with avirulent mutants, where co-inoculated or second-inoculated virulent cells colonized the stem tissue at a high density (18).

For further development of this method, two ways can be proposed. First, a strain of interest just isolated from a wilted plant on site can be converted to avirulent by infection with $\phi R S M$ phage for biocontrol purpose. This avirulent strain may be inoculated into healthy plants growing around the wilting spot to prevent further infection and expansion of the disease. Second, crop seedlings or young plants grown in nursery pots can be treated with $\phi$ RSMinfected $R$. solanacearum cells before planting to fields for prevention of bacterial wilt, because the protection effects will be long lasting (for more than 2 months), as demonstrated above. The use of $\phi$ RSM-infected cells for biocontrol of $R$. solanacearum can be used in combination with another method using lytic phages such as $\phi R S L 1(20,38)$, which is most effective for wilt prevention when plant seedlings are treated.

\section{Acknowledgments}

This study was supported, in part, by a Grant-in-Aid from the Ministry of Education, Science, Sport and Culture of Japan (21580095 to T. Yamada).

\section{Literature Cited}

1. Addy, H. S., Askora, A., Kawasaki, T., Fujie, M., and Yamada, T. 2012. Loss of virulence of the phytopathogen Ralstonia solanacearum through infection by $\phi R S M$ filamentous phages. Phytopathology 102:469-477.

2. Adhikari, T. B., and Basnyat, R. C. 1998. Effect of crop rotation and cultivar resistance on bacterial wilt of tomato in Nepal. Can. J. Plant. Pathol. 20:283-287.

3. Alemzadeh, A., Fujie, M., Usami, S., Yoshizaki, T., Oyama, K., Kawabata, T., and Yamada, T. 2006. ZMVHA-B1, the gene for subunit B of a vacuolar $\mathrm{H}^{+}$- ATPase from the eelgrass Zostera marina L., is able to replace vma 2 in a yeast null mutant. J. Biosci. Bioeng. 102:390-395.

4. Araujo, J. S., de Rodrigues, P., Ribeiro, de L. D., Goncalves, K. S., and Polidoro, J. C. 2004. Bacteriocin production by Brazilian isolates of Ralstonia solanacearum in vitro. ISHS. Acta Hortic. 695:313-320

5. Askora, A., Kawasaki, T., Usami, S., Fujie, M., and Yamada, T. 2009. Host recognition and integration of filamentous phage $\phi R S M$ in the phytopathogen, Ralstonia solanacearum. Virology 384:69-76.

6. Boucher, C. A., Barberis, P. A., Trigalet, A. P., and Demery, D. A. 1985. Transposon mutagenesis of Pseudomonas solanacearum: isolation of Tn5 induced avirulent mutants. J. Gen. Microbiol. 131:2449-2457.

7. Boucher, C. A., Gough, C. L., and Arlat, M. 1992. Molecular genetics of pathogenicity determinants of Pseudomonas solanacearum with special emphasis on hrp genes. Annu. Rev. Phytopathol. 30:443-461.

8. Champoiseau, P. G., Jones, J. B., and Allen, C. 2009. Ralstonia solanacearum race 3 biovar 2 causes tropical losses and temperate anxieties. Plant Health Progress. Online publication. doi:10.1094/PHP-2009-0313-01-RV

9. Chen, W. Y., and Echandi, E. 1984. Effects of avirulent bacteriocin-producing strains of Pseudomonas solanacearum on the control of bacterial wilt of tobacco. Plant Pathol. 33:245-253.

10. Ciampi-Panno, L., Fernandez, C., Bustamante, P., Andrade, N., Ojeda, S., and Contreras, A. 1989. Biological control of bacterial wilt of potatoes caused by Pseudomonas solanacearum. Am. J. Potato Res. 665:315-332.

11. Ciardi, J. A., Tieman, D. M., Lund, S. T., Jones, J. B., Stall, R. E., and Klee, H. J. 2000. Response to Xanthomonas campestris pv. vesicatoria in tomato involves regulation of ethylene receptor gene expression. Plant Physiol. 123:81-92.

12. Cunnac, S., Boucher, C., and Genin, S. 2004. Characterization of the cisacting regulatory element controlling HrpB-mediated activation of the type III secretion system and effector genes in Ralstonia solanacearum. J. Bacteriol. 186:2309-2318.

13. Dann, E. K., and Deverall, B. J. 2000. Activation of systemic disease re- sistance in pea by an avirulent bacterium or a benzothiadiazole, but not by a fungal leaf spot pathogen. Plant Pathol. 49:324-332.

14. Denny, T. P. 2006. Plant pathogenic Ralstonia species. Pages 573-644 in: Plant-Associated Bacteria. S. S. Gnanamanickam, ed. Springer, Amsterdam.

15. Dong, C., Zeng, X., and Liu, Q. 1999. Biological control of tomato bacterial wilt with avirulent bacteriocinogenic strain of Ralstonia solanacearum. J. Sci. China Agric. Univ. 20:1-4.

16. Edreva, A. 2004. A novel strategy for plant protection: induced resistance. J. Cell. Mol. Biol. 3:61-69.

17. El Albyad, M. S., el Sayed, M. A., and el Shanshoury, A. R. 1996. Effect of culture conditions on the antimicrobial activities of UV-mutants of Streptomyces corchorusii and $S$. spiroverticillatus against bean and banana wilt pathogens. Microbiol. Res. 151:201-211.

18. Frey, P., Prior, P., Marie, C., Kotoujanski, A., Trigalet-Demery, D., and Trigalet, A. 1994. Hrp mutants of Pseudomonas solanacearum as potential biocontrol agents of tomato bacterial wilt. J. Bacteriol. 60:3175-3181.

19. Fujie, M., Takamoto, H., Kawasaki, T., Fujiwara, A., and Yamada, T. 2009. Monitoring growth and movement of Ralstonia solanacearum cells harboring plasmid pRSS12 derived from bacteriophage $\phi R S S 1$. J. Biosci. Bioeng. 109:153-158.

20. Fujiwara, A., Fujisawa, M., Hamasaki, R., Kawasaki, T., Fujie, M., and Yamada, T. 2011. Biocontrol of Ralstonia solanacearum by treatment with lytic bacteriophages. Appl. Environ. Microbiol. 77:4155-4162.

21. Genin, S., and Boucher, C. 2004. Lessons learned from the genome analysis of Ralstonia solanacearum. Annu. Rev. Phytopathol. 42:107-134.

22. Griesbach, E., Eisbein, K., Krämer, I., Muller, J., and Völksh, B. 2000. Induction of resistance to bacterial pathogens in the pathosystem tomato/Clavibacter michiganensis subsp. michiganensis. I. Characterization of the resistance induction. J. Plant Prot. 107:449-463.

23. Guo, G. H., Qi, H. Y., Guo, Y. H, Ge, H., Gong, L. Y., Zhang, L. X., and Sun, P. H. 2004. Biocontrol of tomato wilt by plant growth-promoting rhizobacteria. Biol. Control 29:66-72.

24. Hayward, A. C. 2000. Ralstonia solanacearum. Pages 32-42 in: Encyclopedia of Microbiology, Vol. 4. J. Lederberg, ed. Academic Press, San Diego, CA.

25. Horita, M., and Tsuchiya, K. 2002. Pages 5-8 in: MAFF Microorganism Genetic Resources Manual, No. 12. National Institute of Agricultural Sciences, Tsukuba, Japan.

26. Kawasaki, T., Satsuma, H., Fujie, M., Usami, S., and Yamada, T. 2007. Monitoring of phytopathogenic Ralstonia solanacearum cells using green fluorescent protein-expressing plasmid derived from bacteriophage $\phi \mathrm{RSS} 1$. J. Biosci. Bioeng. 104:451-456.

27. McLaughlin, R. J., Sequeira, L., and Weingartner, D. P. 1990. Biocontrol of bacterial wilt of potato with an avirulent strain of Pseudomonas solanacearum: interactions with root-knot nematodes. Am. J. Potato Res. 67:93-107.

28. Negishi, H., Yamada, T., Shiraishi, T., Oku, H., and Tanaka, H. 1993. Pseudomonas solanacearum plasmid pJTPS1 mediates a shift from the pathogenic to nonpathogenic phenotype. Mol. Plant-Microbe Interact. 6:203-209.

29. Poueymiro, M., Cunnac, S., Barberis, P., Deslandes, L., Peeters, N., CazaleNoel, A. C., Boucher, C., and Genin, S. 2009. Two type III secretion system effectors from Ralstonia solanacearum GMI1000 determine host-range specificity on tobacco. Mol. Plant-Microbe Interact. 22:538-550.

30. Schoonejans, E., Expert, D., and Toussaint, A. 1987. Characterization and virulence properties of Erwinia chrysanthemi lipopolysaccharide-defective, Phi EC2-resistant mutants. J. Bacteriol. 169:4011-4017.

31. Silveira, E. B., Da, R., Mariano de, L. R., and Michereff, S. J. 1995 Antagonism of Bacillus spp. against Pseudomonas solanacearum and effect on tomato seedling growth. Fitopatol. Bras. 20:605-612.

32. Smith, J. J., and Saddler, J. 2001. S. The use of avirulent mutants of Ralstonia solanacearum to control bacterial wilt disease. Pages 159-176 in: Biotic Interactions in Plant-Pathogen Associations. M. J. Jeger and N. J. Spence, eds. CABI Publishing, Wallingford, UK.

33. Tanaka, H., Negishi, H., and Maeda, H. 1990. Control of tobacco bacterial wilt by an avirulent strain of Pseudomonas solanacearum M4S and its bacteriophage. Ann. Phytopathol. Soc. Jpn. 56:243-246.

34. Tharaud, M., Laurent, J., Fake, M., and Paulin, J. P. 1997. Fire blight protection with avirulent mutants of Erwinia amylovora. Microbiology 143:625-635.

35. Trigalet, A., and Trigalet-Demery, D. 1990. Use of a virulent mutants of Pseudomonas solanacearum for the biological control of bacterial wilt of tomato plants. Physiol. Mol. Plant Pathol. 36:27-38.

36. Van Loon, L. C., and Van Strien, E. A. 1999. The families of pathogenesisrelated proteins, their activity and comparative analysis of PR-1 type proteins. Physiol. Mol. Plant Pathol. 55:85-97.

37. Winstead, N. N., and Kelman, A. 1952. Inoculation techniques for evaluating resistance to Pseudomonas solanacearum. Phytopathology 42:628634.

38. Yamada, T., Kawasaki, T., Nagata, S., Fujiwara, A. Usami, S., and Fujie, M. 2007. New bacteriophages that infect the phytopathogen Ralstonia solanacearum. Microbiology 153:2630-2639. 